IRA-International Journal of Education \& Multidisciplinary Studies

ISSN 2455-2526; Vol.04, Issue 02 (2016)

Pg. no. 243-250

Institute of Research Advances

http://research-advances.org/index.php/IJEMS

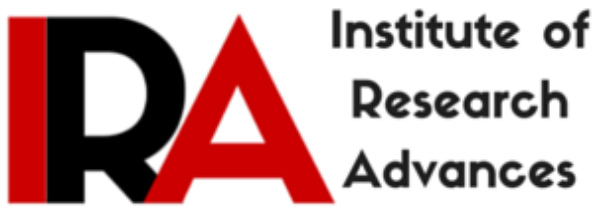

\title{
Courseware on IFRS (A Must): A Strategic Review for B-Schools in India
}

\author{
Dr. Vidhi Bhargava \\ HOI Amity College of Commerce \\ Amity University, India.
}

Type of Review: Peer Reviewed

DOI: http://dx.doi.org/10.21013/jems.v4.n2.p3

\section{How to cite this paper:}

Bhargava, V. (2016). Courseware on IFRS (A Must): A Strategic Review for B-Schools in India. IRA International Journal of Education and Multidisciplinary Studies (ISSN 2455-2526), 4(2), 243-250. doi:http://dx.doi.org/10.21013/jems.v4.n2.p3

(C) Institute of Research Advances

\section{(cc) EY-NC}

This work is licensed under a Creative Commons Attribution-Non Commercial 4.0 International License subject to proper citation to the publication source of the work.

Disclaimer: The scholarly papers as reviewed and published by the Institute of Research Advances (IRA) are the views and opinions of their respective authors and are not the views or opinions of the IRA. The IRA disclaims of any harm or loss caused due to the published content to any party. 


ABSTRACT
The present paper is a humble exercise on the strategic issues in the courseware demanding
attention of planners and operators of commercel accounting education in general and B Schools
in particular in India. The paper briefly does include some expression on the realisation of the
inclusion of imparting adequate knowledge on IFRS through right methods for product
differentiation or brand building by the institutions as an essential ground for the strategy
development. Therefore, the paper introduces a brief account of chronological developments and
benefits of IFRS. In the main, the paper embodies a widely referred re view of strategic issues
involved in implementing a courseware on IFRS with respect to curriculum impact, institutional
aspects, professional thrust and the perception of the both the counter parts of the teaching-
learning i.e. faculty and students leading to the challenges the managers and regulators of these
institutes are faced with.

Key Words: Courseware, IFRS, curriculum, education.

As India strives ahead on the path of economic development, Indian companies need to unify as well as compete with global peers for all the aspects of business growth \& sustenance. Our financial reporting thus also has to be based on globally accepted standards. The pace of IFRS implementation in Indian corporate is perfectly in line with the global momentum towards convergence and superior quality of financial reporting. A concrete strategy combined with complete support from leadership accompanied by healthy teamwork will be a necessity to migrate successfully to the new system. In fact, a carefully designed communication strategy would come handy for this transition. This communication could be the best if it is to our upcoming professionals at Pre University and University level. So in this paper we tend to talk about the various aspects involved with IFRS and its inclusion in the curriculum in the education system in India.

\section{Chronological Development of International Accounting Standards}

1966 - Proposal to establish an International Study Group comprising Institute of Chartered Accountants of England \& Wales (ICAEW), American Institute of Certified Public Accountants (AICPA) and Canadian Institute of Chartered Accountants (CICA).

1967 - Foundation of Accountants International Study Group (AISG) laid.

1973 - International Accounting Standards Committee (IASC) came into existence. IASC set Accounting Standards (IAS 1 to IAS 41) and survived for 27 years until 2001.

1997 - The Standard Interpretations Committee (SIC) was established to consider contentious accounting issues that needed guidance internationally to stop widespread variation in practices.

2001 - IASC restructured itself to form International Accounting Standards Board (IASB) and issued series of new standards called IFRS.

2003 - The first IFRS was published IFRS1: First time adoption of IFRS.

In India the Accounting Standards Board (ASB) was constituted by the Institute of Chartered Accountants of India (ICAI) on $21^{\text {st }}$ April 1977 with the function of formulating Accounting Standards. The first Indian Accounting Standards (AS) came into existence in 1977. The Indian Accounting Standards (AS), are relatively simple, suited to meet the requirements of simpler organisations. But today's businesses are complex and diversified in various parts of the world. So Indian Accounting Standards need improvement in a large number of areas like consolidation,

\footnotetext{
${ }^{1}$ Here the term courseware is considered as a wider term against the usual connotation of curriculum or course design.
} 
group accounts, accounting for mergers and acquisitions, financial instruments, share based compensation, revenue recognition etc. Consequently some entities may have to face thorough wipe off of their retained earnings while for some the case may be reverse.

In Feb 2011, IFRS converged Indian Accounting Standards (Ind. AS) came to the forefront. But owing to the costs and other challenges involved, implementation of the new converged standards is postponed until April 2012. However subsequent changes in IFRS in 2013 would further require changes in Ind. AS and further delay in complete implementation (Khatri J 2011). In almost all parts of the world, researches indicate increased market liquidity \& better credit rating for firms post the IFRS adoption. However researchers do not establish statistical valid connection between IFRS and low cost of capital but still some relativity seems to exist. (Lima, Sumpio) As regards the IFRS implementation status, the adopters can be classified into 3 categories:-

1. Those that have already adopted mandatory IFRS

2. Those that have set up a time frame for adoption.

3. Those who have no full plan in place.

We ironically fall in the second category.

\section{Benefits of IFRS Adoption}

Diversity in Accounting Standards not only means additional cost of financial reporting but can cause difficulties to multinational groups in the manner in which they undertake transactions. Harmonization of Accounting Standards would improve international comparability of Financial Statements \& thus attract new investors.

The benefits derived from IFRS convergence are numerous. Enhanced comparability and reporting transparency are prime. Other benefits include lowering the cost of raising capital due to minimal reporting efforts and reductions in risk premium built by investors. Another benefit is that of cost saving primarily for multinational organisations who may have to prepare two sets of statements, i.e. one for domestic and the other for international motives.

By adopting IFRS, it is expected an increase in the disclosure quality of Financial Statements of companies. This will have an inverse effect on the information asymmetry and on the risk, which consequently reduce the cost of capital. Sir David Tweedie (Former President of IASB) share the same view, when saying regarding the IFRS, they: "[......] should reduce the cost of capital and open new opportunities for diversification and improved investment returns."

Switching over to IFRS is much more than just a technical procedure. The implications are much more extensive than reporting issues, and stretch to a number of business and regulatory issues including that of compliance, with debt covenants, ESOP schemes restructuring, training, IT Systems up gradation and tax planning. It also helps in reporting to the management, which may be in another country.

\section{Curriculum Impact (Higher Education)}

Regardless of the varying opinions and study results, convergence of local accounting standards to IFRS is now more of a reality rather than a simple forum for discussion.

"We need to educate them (today's students) for the world they will live in. Their world is global" (Barth 2008). One significant aspect is to assess the readiness of "all parties involved in the financial reporting process, including investors," for a conversion to IFRS, which may require changes to the university accounting curricula (SEC 2010a).

IFRS enforces a shift from a rules based approach to a principle based approach in financial reporting. This shift would require the preparers and auditors of Financial Statements to utilize 
more critical thinking skills. The IFRS will force individuals to take aggressive steps in interpreting and will have to apply intuitive skills to be able to take decisions in environment of uncertainty. The accounting educators, the major accounting firms, the professional institutes associated with accounting and the accounting textbook publishers need to recognise the urgency for this shift. Thus the convergence and transition process would not only put irresistible pressure on accounting educators to become accustomed in teaching a whole new set of rules but also change the teaching methodology that would help built skills in applying strategic judgement to identify the substance of events. The reason being IFRS provides companies more flexibility to use judgement in revenue recognition and other key areas.

Studies conducted in various countries like Australia (Crosling, Edwards \& Sehroder 2008) and Russia (Preobragenskaya \&Mc Gee 2003) on internationalising the business/ accounting curriculum reverberate identical challenges being faced by educators of accounting and the dire need for institutional support. Unfortunately, such official inputs are not adequately available in India.

Now the question arises what should academics do in this fluid regulatory environment? Since IFRS has been adopted worldwide, should Universities be incorporating IFRS in the curriculum? Who would teach, how the courseware is to be designed, how would the faculty be trained, at what level of education should IFRS be incorporated? Adding IFRS to an already robust curriculum would require two set of standards to be taught? The corporate world is requiring that new hires be familiar with IFRS. Such questions are being taken care of all over the world. Cunningham (2008) says the entire US training, education and examination system requires revision. Munter \& Reckers (2009) report on significant impediments in integrating IFRS in US collegiate accounting curriculum.

\section{Institutional Aspects}

Indian educational institutions and business schools in particular, need to decide their role in preparing students for a comprehensive economic environment that is IFRS compliant or shall be in the very near future. As of now, very few educational institutions have a strategy in place as to the incorporation of IFRS in accounting curricula. Dow and Feldmann (1997) indicate that the size of the accounting department, teaching load, and class size are all related to the use of cases in intermediate accounting, while Alvarez McHatton et al. (2009) highlight that time constraints weigh heavily on the decision to voluntarily add extra content to the curriculum. Furthermore, Neumann (1992) suggests that research interests at the departmental level provide direction for the framework of courses offered, which is corroborated by Mayhew and Grunwald (2006), who find that faculty members are more likely to cover diversity in their classes when they perceive that their department is committed to diversity. The administration (department, business school, or university) likely plays a significant role in curriculum development by establishing course objectives and assessment, and determining paths to graduation, which therefore influence the discretionary class time available to instructors in an already overcrowded curriculum (Tondkar et al. 1998; Adhikari et al. 1999).

In a country like India IFRS in curriculum could be a challenge also because at time it would be difficult for the administration to understand the significance of being global in teaching \& learning. Probably, the university administration does not truly understand \& appreciate the change needed. So it is again the duty of professor to educate the administration about overall impact of IFRS in business developing \& brand building and be a differentiator in the society. Blight et al (2000) suggest that a large international student population leads to "internationalization of the curriculum".

\section{Faculty Perceptions}

The faculty that believes the transition to IFRS in India to be certain would definitely cover IFRS in depth in their teaching. But the intensity of coverage is significantly related with the 
presence of colleagues interested in teaching International issues, specifically in Accounting. Also, the decision of inclusion of IFRS in the curriculum at any level of education will always be made in a group. This, in terms of faculty characteristics will depend significantly upon association with the industry, because greater exposure in practice would prompt greater coverage to the issue in classroom.

In accounting education, Watson et al. (2007) suggest that faculty issues such as professional experience have a direct impact on course delivery methods and ultimately impact the skills and knowledge of the students. Mounce et al. (2004) suggest that student perceptions of instructor quality are linked to industry experience. Nilsen (2008) suggests that students' awareness of IFRS is generally low, and for the most part, the awareness is driven by faculty in conjunction with large public accounting firms.

In fact, those interested in International Accounting research will be more likely to teach and expertise working with IFRS leading to a positive impact as regards to IFRS in curriculum. Additionally, practitioners (may be part time) might also be interested in understanding practical implications of IFRS in the introduction of Accounting Courses. As their clients switch or look forward to switch from old reporting practices to IFRS reporting, a basic understanding of IFRS by the clients, many of whom would be non accounting personnel, may help smooth transition. Hence, educators need to develop knowledgeable (updated) financial statement users.

Probably, the uncertainty regarding the total transformation to IFRS statements may be contributing to the probable lack of its infusion in the accounting curriculum. The inadequacy of IFRS teaching material in the course ware as well as text books may also be one of the practical barriers to overcome which the faculty themselves have to be the initiator \& go ahead for self learning \& training. The additional workload or self preparation and training may also be one of the reasons for this reluctance of IFRS penetration in the curriculum.

KPMG - AAA Faculty Survey was conducted. The major findings of the study pointed towards IFRS adoption in curriculum at intermediate levels and above in USA would be probably after 2012. By then the educational institutions would have a clear picture as to the extent of adoption, policy structures and other frameworks. In the survey more than $50 \%$ of professors accepted the teaching of IFRS in the curriculum as a comparative study with US GAAP.

\section{Professional Thrust}

Convergence to IFRS will not only benefit accounting professionals in the way that they would be able to sale their expert services in different parts of the world and that too at very high credentials. But this would also require them to be proficient and well updated to the latest structures and analytics of analysing and recognising various items of finances.

The thrust to convergence has actually been initiated by accountants in public practice. The convergence would offer them more prospects in various parts of the world if same accounting practices are prevalent across the globe. The mobility of professionals would increase and they can conveniently quote IFRSs to clients to recommend ways of reporting. Christopher Wright \& Steven Hobbs (2010) says, "This new dynamic will likely affect the staffing mix and leverage of audit engagements. For these reasons, our view is that there will be an increase in the external auditor's fees when performing an audit of the company's financial statements during the first year of conversion to or convergence with IFRS. Over time, as external auditors gain more experience with IFRS, not to mention confidence in management's exercise of judgement in interpreting and applying the new standards, we expect audit fees to decline and return to amounts relatively comparable to pre-conversion fee levels." 


\section{Student Viewpoint}

Firms like PWC expect sophomore to have a basic understanding of the new future significance of IFRS and internship and job applicants to know the sources of GAAP and IFRS, have a familiarity with the new reporting standards, be able to identify differences, accounting professors must begin exposing students now so that they will be competent in the job market. The product of our universities \& colleges are input directly into the corporate world where they are supposed to be aware about the new technologies and changing environment of the business. But the irony is that whatever they study in the classroom is completely different from what they have to implement in the organisation. IFRS is one of such example.

ICAI and some other very few institutes/ universities have incorporated IFRS in their syllabus. ICAI has introduced some modules in the chartered accountancy courseware. But apart from CAs there are a huge lot of students who have to experience challenges in the corporate world. As said earlier there are a few private institutes that are microscopic in number that offer some courses in IFRS but those are beyond the reach of an average Indian student. Even if a student goes for some sort of short term or certificate course it is just like a one month trainee in cardiology performs an open heart surgery. Actually a lot will depend on the type of students an organisation admits. If the number of International students is large, the demand of international courses in accounting would increase \& so IFRS would soon be a part of curriculum.

\section{Challenges}

In India we need to establish culturally sensitive education and professional training program. The challenge lies in setting a widespread change management program for various sections of the society, may it be accounting professionals, businesses, government or the public with the necessary change management tools to make a successful transition.

The cost of IFRS implementation is also an issue of concern because before one can realise the cost saving, transition costs are exorbitant. These include costs related to preparation, certification, dissemination of reports, and opportunity costs. Updating computer systems, hiring specialists and consultants, updating formats and training personnel are some challenges to be dealt with.

According to the SEC estimate, those adopting IFRS early would incur about $\$ 32$ million in additional cost in filing Financial Statements. Intel had quoted an estimate of $\$ 50$ million for IFRS conversion (Johnson \& Leone 2009). Accounting faculty shortage, inadequate support from educational institutions and text book publishers are main challenges for integrating IFRS in the curricula. Educators need to change the way accounting is being taught so as to develop conceptual thinking. The current environment is also ripe for publication of specific cases with real corporate examples demonstrating practical differences on controversial topics. Such cases will prove to be best suitable tools for training accounting students with the required skills for interpreting and auditing the principles based approach under IFRS.

\section{Conclusion}

To conclude IFRSs adoption in Indian companies should have culminate somewhere in 2014, but this is not the case. Large firms have compiled IFRS resources, begun training the staff, and also started pushing academia to incorporate IFRS in the classroom, but little has been done even till today. The difficulties with professors are to search and assimilate all of the available resources, develop a curriculum to work in classroom, educate themselves in all potential modifications. Course work will need to be designed to meet the student requirements so that they are able to communicate, analyse and utilise critical, analytical and thinking skills. So accounting departments actually need to start developing curriculum changes and make the syllabi futuristic. A collective exercise is badly required by all stake holders except students. But ofcourse giving 
due attention to the viewpoint of who being a non participating but significant stake holder present in the process for whom the ultimate exercise is to be done.

\section{BIBLIOGRAPHY}

1. Alvarez McHatton, P., H. Keller, B. Shircliffe, and C. Zalaquett. 2009. Examining efforts to infuse diversity within one college of education. Journal of Diversity in Higher Education 2 (3): 127-135.

2. Barth, M. E. 2008. Global financial reporting: Implications for U.S. academics. The Accounting Review 83(5): 1159-1179.

3. Blight, D., D. E. Davis, and A. Olsen. 2000. The globalisation of higher education. In Higher Education Re-Formed, edited by P. Scott. London, U.K.: Falmer Press.

4. Bolt-Lee, C., \& Smith, L. M. (2009, November). Highlights of IFRS research. Journal of Accountancy, Retrieved May 15, 2010, from: http://www.journalofaccountancy.com.

5. Christopher Wright and Steven Hobbs, 2010, Impact and Implications of IFRS Conversion or Convergence, Bank Accounting and Finance, June-July 2010, pp 21-28.

6. Concept paper on Convergence of IFRSs In India, ICAI

7. Cunningham, L. A. (2008). The SEC's global accounting vision: A realistic appraisal of a Quixotic quest. North Carolina Law Review, 87. 27.

8. Dow, K. J., and D. A. Feldmann. 1997. Current approaches to teaching intermediate accounting. Issues in Accounting Education 12 (1): 61-75.

9. EY Guide on Transition to IFRS, Thinking IFRS?, Ernst \& Young

10. Johnson, S., \& Leone, M. (2009). CFOs on IFRS: Forget about it. Retrieved April 17, 2009, from: http://www.cfo.com/article.cfm/13517383?f=search.

11. Khatri, J. (2011). The Economic Times.

12. Lima, V. S., Sampaio, G. A., De Lima, F., de Cavallio, N. G., \& Lima, I. S. (2010). Toward IFRS: Economic Consequences of Accounting Convergence in an Emerging Economy. Research in Emerging Economies, 10, 251-295.

13. Mounce, P. H., D. S. Mauldin, and R. L. Braun. 2004. The importance of relevant practical experience among accounting faculty: An empirical analysis of students' perceptions. Issues in Accounting Education 19 (4): 399-411.

14. Munteanu Lucian, (2011). The benefits of IFRS adoption- A survey of Chief Financial Officers of Romanian Listed Companies. World academy of science, engineering and Technology, vol 59. pp 1554-1559

15. Munter, P., \& Reckers, P. M. J. (2009). IFRS and collegiate accounting curricula in the United States: 2008 a survey of the current state of education conducted by KPMG and the Education Committee of the American Accounting Association. Issues in Accounting Education. 24(2).131.

16. Munter, P., and P. M. J. Reckers. 2009. IFRS and collegiate accounting curricula in the United States: 2008 a survey of the current state of education conducted by KPMG and the Education Committee of the American Accounting Association. Issues in Accounting Education 24 (2): 131-139.

17. Neumann, R. 1992. Perceptions of the teaching-research nexus: A framework for analysis. Higher Education 23 (2): 159-171.

18. Nilsen, K. 2008. Time to think differently. Journal of Accountancy 206 (5): 42-45.

19. Oguri, T. (2002). A theoretical Survey of Critical Accounting Studies in Japan. Crtical Perspectives on Accounting, 13(4), 477-495.

20. Preobragenskaya, G.G., \& McGee, R.W. (2003). Accounting education in a transition economy: A case study of Russian universities. Retrieved June 1, 2009, from: http://ssrn.com/abstract=459361.

21. S.D. Tweedie, Prepared Statement of Sir David Tweedie, Chairman Of the IASB, before the economic and monetary affairs committee of the European Parliament, (2006). 
22. Sherman, R. W. 1987. Internationalizing the accounting curriculum. Journal of Accounting Education 5 (2): 259-275.

23. Stark, J. S., and L. R. Lattuca. 1997. Shaping the College Curriculum: Academic Plans in Action. Needham Heights, MA: Allyn \& Bacon.

24. Tondkar, R. H., M. A. Flanigan, A. Adhikari, and J. A. Hora. 1998. Internationalizing accounting education through an integration approach: A survey of U.S. schools. International Journal of Accounting 33(4): 483-507.

25. Zhu Hong, Rich Kevin T., Michenzi Alfred R., Cherubini Jason (2011). User-Oriented IFRS Education in Introductory Accounting at U.S. Academic Institutions: Current Status and Influencing Factors, Issues in Accounting Education, American Accounting Association, vol 26, no4, pp 725-750. 